Matematikai Közlemények

IX. kötet, 2021

doi:10.20312/dim.2021.03

\title{
Az erdei szalonka (Scolopax rusticola L.) Magyarországi tavaszi vonulásának modellezése nemlineáris regressziós eljárások segítségével
}

\author{
Bende Attila \\ Soproni Egyetem \\ Vadgazdálkodási és Vadbiológiai Intézet \\ bende.attila@uni-sopron.hu \\ Csanády Viktória \\ Soproni Egyetem \\ Informatikai és Matematikai Intézet \\ csanady.viktoria@uni-sopron.hu \\ $\dagger$ Csanády Etele \\ Soproni Egyetem \\ László Richárd \\ Soproni Egyetem \\ Vadgazdálkodási és Vadbiológiai Intézet \\ laszlo.richard@uni-sopron.hu
}

\begin{abstract}
ÖSSZEFOGLALÓ. Az erdei szalonka (Scolopax rusticola L.) tavaszi vonulásának elemzése során a vonulás dinamikai jellegzetességeinek modellezéséhez olyan speciális függvényeket adaptáltunk és illesztettünk, amelyek alkalmasak a folyamat jellemzésére, az eltéréseinek kifejezésére és azok matematikai módszerekkel történő értékelésére. Eredményeink alapján az alkalmazott módszerek közül a Gauss-függvények speciális lineáris kombinációi bizonyultak a legalkalmasabbnak az egyes évek vonulásdinamikai sajátságainak elemzésére. E függvények nagy pontossággal $(\mathrm{R}=90,3 \%-98,7 \%)$ írták le a faj tavaszi vonulását még a szélsőséges adatsorokkal jellemezhető években is. Eredményeink alapján javasoljuk az általunk alkalmazott Gauss-függvények speciális lineáris kombinációinak alkalmazását más madárfajok vonulási karakterisztikájának értékelésére is.
\end{abstract}

ABSTRACT. In the analysis of the spring migration of the woodcock (Scolopax rusticola L.), specific functions were adapted and fitted to model the dynamic characteristics of the migration, which are suitable for characterizing the process, expressing its variations and evaluating them by mathematical methods. Based on our results, the special linear combinations of Gaussian functions were found to be the most suitable for migration dynamics analysis for each year. These functions described the spring migration of the species with high accuracy ( $\mathrm{R}=90.3 \%-98.7 \%)$, even in the years characterized by extreme data series. Based on our results, we propose the use of special linear combinations of our Gaussian functions to evaluate the migration characteristics of other bird species.

KULCSSZAVAK. Erdeiszalonka-vonulás, vonulásmodellezés, nemlineáris regresszió, Awrami-modell, Gauss-modell

KEYWORDS. Woodcock migration, migration modelling, nonlinear regression, Awrami-model, Gaussmodel 


\section{Bevezetés}

Az EU madárvédelmi direktívája a vadászati törvénybe (1996. évi LV.), annak 2008-as módosítása során került be, aminek következtében 2009-től kezdődően ugyan vadászható faj maradt az erdei szalonka, de vadászati idényt nem állapítottak meg rá. A direktívától való eltérés feltételeként az Országos Magyar Vadászati Védegylet koordinálásával, 2009-ben vette kezdetét a Szent István Egyetem által vezetett megfigyeléses Erdei Szalonka Monitoring, amihez 2010-ben biometriai vizsgálati modullal csatlakozott a Nyugat-Magyarországi Egyetem (ma Soproni Egyetem), Erdőmérnöki Karának Vadgazdálkodási és Gerinces Állattani Intézete. A fenti munka nyomán páratlan lehetőség kínálkozott az erdei szalonka tavaszi vonulásának nagy elemszámú minta alapján történő idősoros vizsgálatára.

Kutatva a modellalkotás lehetőségeit a madárvonuláskutatásban a szakirodalomban nem találhatunk olyan matematikai módszert, amely alkalmas lett volna az általunk vizsgált madárvonulás megfelelő modellezésére. Az alkalmazott eljárások jellemzően vonaldiagrammok segítségével jellemzik a folyamatokat, amelyek ugyan szemléletesek, de a segítségükkel végzett vizsgálatok - a ponthalmazok összehasonlítási lehetőségei - nagyon felületesek, mégis ezek a megoldások a legelterjedtebbek.

\section{Anyag és módszertan}

A 2010-es év tavaszától az Országos Magyar Vadászati Védegylet koordinálásával müködő Erdei Szalonka Teríték Monitoring alapozta meg a faj tavaszi vonulásdinamikájának országos léptékü, nagy elemszámú vizsgálatát. A mintavétel során rögzítésre került a madarak elejtésének helye (megye, település, gazdálkodó) és a mintavétel pontos ideje (hónap, nap, óra, perc). A mintavételi adatlapok az első időszakban (2010-2014) a Nyugat-Magyarországi Egyetem (ma Soproni Egyetem) Vadgazdálkodási és Gerinces Állattani Intézetébe érkeztek. A monitoring második időszakában (2015-2019) az adatszolgáltatók által beküldött alapadatok (elejtési hely és idő, ivar) a Szent István Egyetemre érkeztek, majd ezeket az intézmény munkatársai továbbították intézetünkbe. A fenti adatgyüjtő munka eredményeképpen 23539 erdei szalonka vonulási adataiból építettünk adatbázist a 2010 és 2019 közötti tavaszi vonulásdinamika értékeléséhez. Az vizsgálat során az elejtések számának időbeli változását arányosnak tekintettük a tavaszi vonulás során átvonuló madarak mennyiségének változásával, tehát az elejtések eredményei hủen tükrözik a Magyarországon átvonuló erdei szalonka állományok tavaszi vonulásának időmintázatát [1]. Célunk olyan nemlineáris regressziós függvények adaptálása és illesztése volt, amelyek alkalmasak a faj vonulásdinamikai sajátságainak modellezésére és az eltérések szemléletes kifejezésére, azok értékelésére.

$\mathrm{Az}$ alapadatbázisok kezelését és a leíró statisztikai elemzéseket Microsoft Excel 2016 program, míg a függvényillesztéseket Statistica 13 program segítségével végeztük. A modellek szélsőértékeinek koordinátáit WinPlot 10.7 programmal határoztuk meg. Az adatok statisztikai elemzését, valamint azok grafikus megjelenítését Microsoft Excel 2016 és Statistica 13 program segítségével végeztük. 


\section{Eredmények}

Az egyes mintavételi napokhoz tartozó elejtési számok koordinátapárjai által kirajzolt ponthalmaz sajátságaihoz igazodó, szerkesztett modellek segítségével jellemeztük az erdei szalonka tavaszi vonulásdinamikáját. Az alkalmazott statisztikai módszer a nemlineáris regresszió számítás, amely során az alkalmasnak vélt tesztelt modellek segítségével írtuk le a folyamatot. A modelleknek számos kritériumnak kellett megfelelnie, úgymint a zárt értelmezési tartományon való értelmezhetőség, a korlátosság tulajdonsága, továbbá a folyamat jellemzése szempontjából kiemelt jelentőséggel bíró elvárás, az egy vagy több szélsőérték megléte, továbbá az ezek meghatározását lehetővé tevő differenciálhatóság.

A modellalkotáshoz először az Awrami-függvény szolgáltatott alapot. E függvény mivel telítődési függvény - alapfüggvény formájában, kellő transzformálás és megfelelő parametrizálás hiányában nem alkalmas a vizsgálatunk tárgyát képező adathalmaz modellezésére, így - egy az erdei szalonka vonulási karakterisztikájához igazodó modellfejlesztésre volt szükség. Ennek megfelelően két egymáshoz képest eltolt helyzetü Awrami-függvény szuperponáltjaként megalkotott kilenc változós modellt [2]. illesztettünk az adatsorokra.

I. modell: A kettős Awrami függvény matematikai alakja:

$$
y=b_{8}-b_{7} \cdot e^{-1 \cdot\left(b_{6} \cdot\left(x-b_{5}\right)\right)^{b_{4}}}-b_{3} \cdot e^{-1 \cdot\left(-1 \cdot b_{2} \cdot\left(x-b_{1}\right)\right)^{b_{0}}}
$$

A kezdőértékek meghatározása az adatsor értékei alapján a következő:

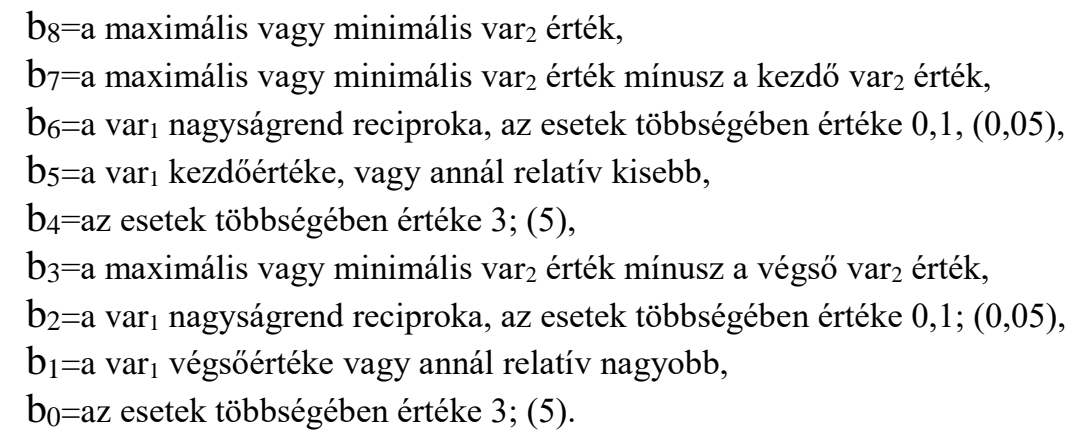

A fenti függvény minden olyan adatsor regressziós vizsgálatára alkalmas, amely adatsorának var 2 értéke (jelen esetben a mintaszám (pld.)) a vizsgálati időszak intervallumán szélsőértékkel rendelkezik és zárt intervallumon (b5<var $1<$ b1) értelmezhető ( 1 ábra). 


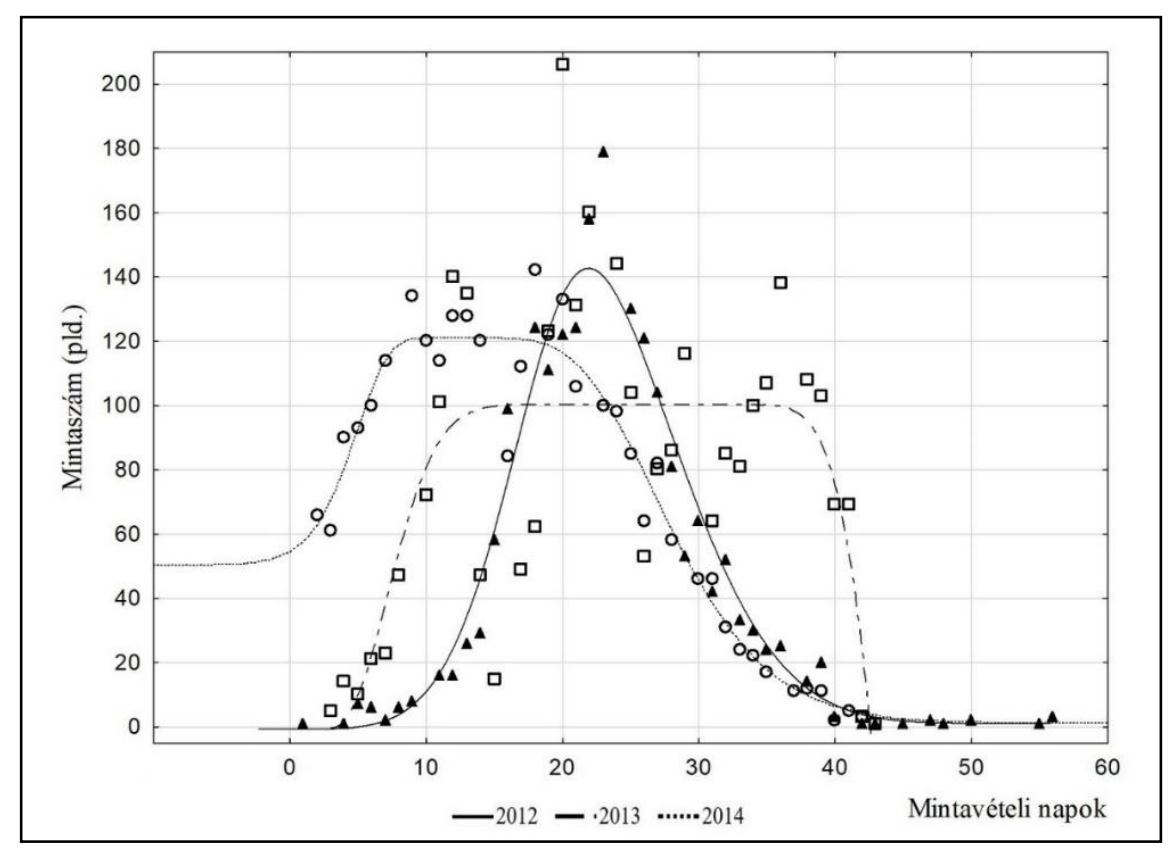

1. ábra: Az alkalmazott kettős Awrami-függvény illesztési eredménye a 2012-es (normál karakterisztikájú), a 2014-es (előretolódó karakterisztikájú) és a 2013-as (szélsőséges, több szélsőértékkel jellemezhető karakterisztikájú) évek tavaszi erdeiszalonka-vonulásának adatsoraira.

Az alkalmazott kettős Awrami-modell rugalmasságát az egyes évek vonulási adatsoraira történő illesztés pontosságát jelző regressziós koefficiensek és a monotonitás értékeit mutatják (1. táblázat).

\begin{tabular}{|c|c|c|c|c|c|}
\hline \multirow{2}{*}{$\mathbf{E} \mathbf{v}$} & \multirow{2}{*}{ Elemszám } & \multirow{2}{*}{$\begin{array}{c}\text { Illesztési } \\
\text { pontosság } \\
(\%)\end{array}$} & \multirow{2}{*}{$\begin{array}{l}\text { Vonulás } \\
\text { tetőzése }\end{array}$} & \multicolumn{2}{|c|}{$\begin{array}{c}\text { Monotonitási jellemző } \\
\text { értékek }\end{array}$} \\
\hline & & & & $\begin{array}{c}\text { Növekedésjelző } \\
(\text { b6*b4 })^{2}\end{array}$ & $\begin{array}{c}\text { Csökkenésjelző } \\
\left(\mathbf{b}_{2} * \mathbf{b}_{0}\right)\end{array}$ \\
\hline 2010 & 2331 & 98,29 & III.21. & 0,2813 & 0,2879 \\
\hline 2011 & 3324 & 98,17 & III.24. & 0,1693 & 0,1693 \\
\hline 2012 & 1889 & 97,70 & III.21. & 0,2715 & 0,2715 \\
\hline 2013 & 2868 & 70,62 & III.19. III.29.* & $0,3913 *$ & $0,2176^{*}$ \\
\hline 2014 & 2681 & 97,70 & III.13. & 0,4762 & 0,4762 \\
\hline 2015 & 2656 & 97,82 & III.18. & 0,2198 & 0,2198 \\
\hline 2016 & 2111 & 95,10 & III.18. & 0,7140 & 0,1895 \\
\hline 2017 & 1660 & 96,75 & III.19. & 0,1666 & 0,2577 \\
\hline 2018 & 1716 & 88,44 & III.21. & 0,1618 & 0,0972 \\
\hline 2019 & 1716 & 96,73 & III.24. & 0,5244 & 0,0959 \\
\hline
\end{tabular}

*Az adatsor hektikussága miatt a vonulás tetőzése és a monotonitás bizonytalanul értékelhető.

1. táblázat: Az erdei szalonka tavaszi vonulásának kettős Awrami-modell szerinti jellemzői a 2010-2019 közötti években. 
Az egy csúcsú, aszimmetrikus karakterisztikát tükröző években a folyamat jellemzésére alkalmasnak bizonyultak az Awrami-függvényekből készített modellek. Azonban a szélsőséges vonulási karakterisztikával (több hullámban zajló vonulás, több szélsőérték) jellemezhető évek adatsorai esetében e függvények alkalmatlanok a folyamat kellő pontosságú leírásához. Így modellalkotásunk során a több szélsőérték megléte esetén is kellő rugalmasságot, s így megfelelö illesztési pontosságot $\left(\mathrm{R}_{2013}=90,35 \% ; \mathrm{R}_{2018}=97,50 \%\right)$ eredményező függvényt választottuk, amihez a közismert Gauss-függvény jelentette az alapot. Az alapfüggvény - a vizsgálati adatsorok jellegéből fakadóan és a függvény ismert szimmetria tulajdonsága miatt transzformáció hiányában nem alkalmas a folyamat jellemzésére. Ennél egy lényegesen rugalmasabb modellre volt szükség, ami a paraméterek számának jelentős növelését tette szükségessé. A fenti követelményeknek az alábbi két Gauss-függvény lineáris kombinációja felet meg.

\section{II. modell: A kettős Gauss-függvény matematikai alakja:}

$$
y=\frac{b_{6}}{e^{\left(b_{5}\left(x-b_{4}\right)\right)^{2}}}+\frac{b_{3}}{e^{\left(b_{2}\left(x-b_{1}\right)\right)^{2}}}+b_{0}
$$

A modellt hét - különböző nyújtási és eltolási - paraméter jellemzi, amelyek biztosítják a függvény kellő rugalmasságát, így az adatsor aszimmetriájához megfelelő illesztési pontossággal igazodó modellt kaptunk.

A kezdőértékek meghatározása az adatsor értékei alapján a következő:

$$
\begin{aligned}
& b_{6}=\text { var2első max. }- \text { var2min. vagy } b_{6}=\text { var2első min.-var2max, } \\
& \mathrm{b}_{3}=\text { var2 másod. max. }- \text { var2min. vagy } \mathrm{b}_{3}=\text { var2 másod. min.-var2 } \max \text {, } \\
& \mathrm{b}_{4}=\text { var1 első max. vagy var1 első min, } \\
& \mathrm{b}_{1}=\text { var1másod. max. vagy var1 másod. min, } \\
& \mathrm{b}_{0}=\operatorname{var}_{2 \mathrm{~min}} \text {, } \\
& \mathrm{b}_{5}=\mathrm{b}_{2} \sim 0,05 \text {. }
\end{aligned}
$$

A szélsőértékek számának növekedése miatt a modellt tovább alakítottuk, így a $\mathrm{b}_{0}$ paraméter helyett egy új Gauss-tag hozzáadásával jutottunk az újabb modellhez.

III. modell: A hármas Gauss-függvény matematikai alakja:

$$
y=\frac{b_{8}}{e^{\left(b_{7}\left(x-b_{6}\right)\right)^{2}}}+\frac{b_{5}}{e^{\left(b_{4}\left(x-b_{3}\right)\right)^{2}}}+\frac{b_{2}}{e^{\left(b_{1}\left(x-b_{0}\right)\right)^{2}}},
$$

Ezen utóbbi modell alkalmazása akkor indokolt, ha a tavaszi vonulás lefolyását a normál évektől eltérően több szélsőérték, szélsőséges dinamika jellemezi (2. ábra).

A kezdőértékek meghatározása az adatsor értékei alapján a következő:

$$
\begin{aligned}
& \mathrm{b}_{8}=\text { var2 első max.-var2 első min, } \\
& \mathrm{b}_{6}=\text { var1 első max, } \\
& \mathrm{b}_{5}=\text { var }_{2 \text { második max.-var2második min, }} \\
& \mathrm{b}_{3}=\text { var }_{1 \text { második max }} \\
& \mathrm{b}_{2}=\text { var }_{2} \text { harmadik max } \\
& \mathrm{b}_{0}=\text { var }_{1} \text { harmadik max } \\
& \mathrm{b}_{7}=\mathrm{b}_{4}=\mathrm{b}_{1} \sim 0,05 .
\end{aligned}
$$




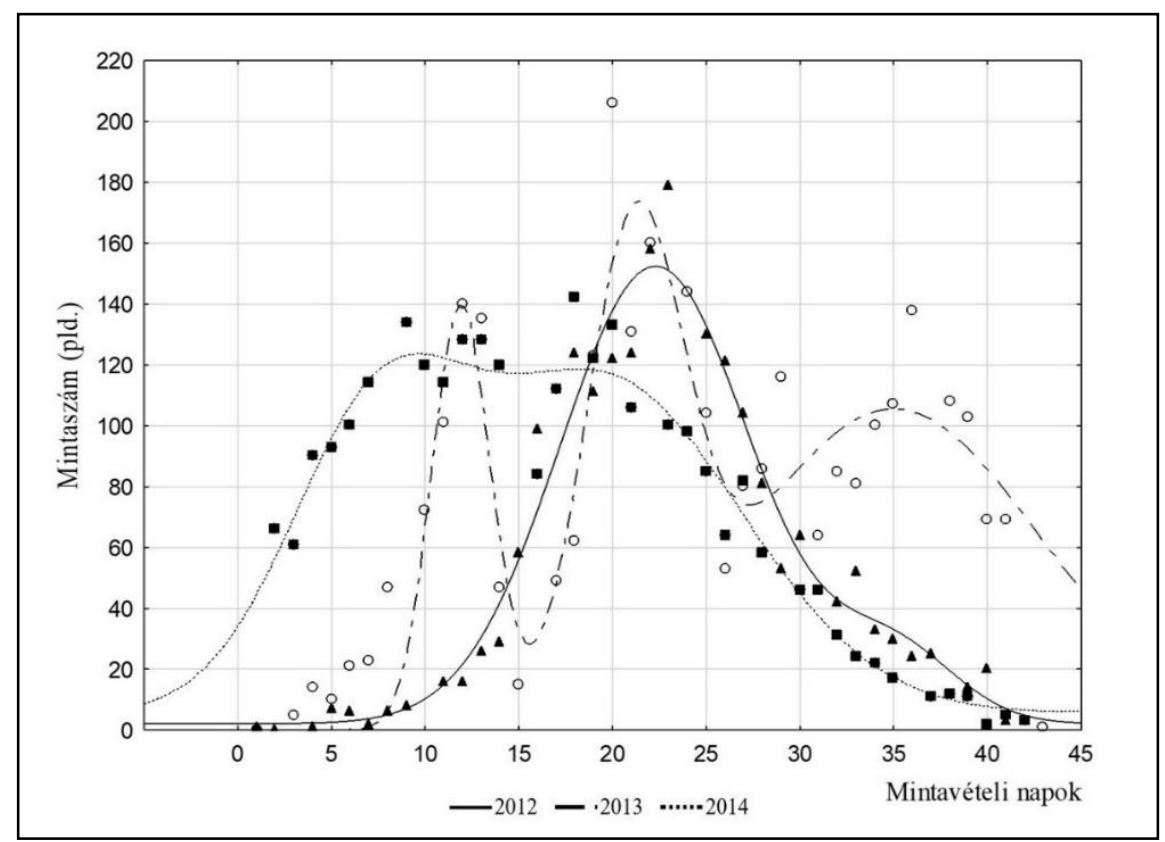

2. ábra: Az alkalmazott kettős és hármas Gauss-modell illesztési eredménye a 2012-es (normál karakterisztikájú), a 2014-es (előretolódó karakterisztikájú) és a 2013-as (szélsőséges, több szélsőértékkel jellemezhető karakterisztikájú) évek tavaszi erdeiszalonka-vonulásának adatsoraira.

A modellek kezdőértékei a vizsgálati adathalmaz értékei alapján a fent jelzett módon a független ( $\left.\operatorname{var}_{1}\right)$ és függő ( $\left.\operatorname{var}_{2}\right)$ változó intervallum határai, illetve a függő változó pontsorozaton belüli legnagyobb és legkisebb értékei, illetve azok helyei alapján számíthatók [3].

\begin{tabular}{|c|c|c|c|c|c|}
\hline \multirow{2}{*}{ Év } & \multirow{2}{*}{ Elemszám } & \multirow{2}{*}{$\begin{array}{c}\text { Illesztési } \\
\text { pontosság } \\
(\%)\end{array}$} & \multirow{2}{*}{$\begin{array}{l}\text { Vonulás } \\
\text { tetőzése }\end{array}$} & \multicolumn{2}{|c|}{$\begin{array}{l}\text { Monotonitási jellemző } \\
\text { differenciahányadosok }\end{array}$} \\
\hline & & & & $\begin{array}{c}\text { Maximum } \\
\text { elött }\end{array}$ & $\begin{array}{l}\text { Maximum } \\
\text { után }\end{array}$ \\
\hline 2010 & 2331 & 97,79 & III. 23. & 8,50 & $-10,23$ \\
\hline 2011 & 3324 & 98,36 & III. 24. & 11,33 & $-14,91$ \\
\hline 2012 & 1889 & 97,95 & III. 22. & 7,11 & $-3,79$ \\
\hline 2013 & 2868 & 90,35 & III. 12., III. 21. & $12,81^{*}$ & $-6,07 * *$ \\
\hline 2014 & 2681 & 97,56 & III. 10. & 6,66 & $-3,78$ \\
\hline 2015 & 2656 & 97,60 & III. 16. & 9,65 & $-5,59$ \\
\hline 2016 & 2111 & 95,41 & III. 08. III.16. & 10,38 & $-2,96$ \\
\hline 2017 & 1660 & 98,74 & III. 19. & 8,68 & $-6,5$ \\
\hline 2018 & 1716 & 97,50 & III. 15., III. 25. & $9,02 *$ & $-7,98^{* * *}$ \\
\hline 2019 & 1716 & 96,31 & III. 17. & 5,57 & $-3,85$ \\
\hline
\end{tabular}

*Az első szélsőértéket megelőző függvényszakaszra vonatkozó differenciahányados.

**Az utolsó szélsőértéket követő függvényszakaszra vonatkozó differenciahányados.

1. táblázat: Az erdei szalonka tavaszi vonulásának kettős és hármas Gauss-modell szerinti jellemzői a 2010-2019 közötti években. 
A faj tavaszi vonulásának modellezésére alkalmazott összetett függvények kezdőértékeinek megadását követően látható, hogy a segítségükkel meghatározott paraméterek mindegyike tényleges információtartalommal bír (pl.: monotonitás jelző értékek meghatározása). Az alapadatokból kalkulált paramétereket $\left(b_{0}, \ldots, b_{8}\right)$ a fent megadott függvényekbe helyettesítve a vonulásdinamika lefolyását jellemző sajátságok matematikai módszerekkel leírhatók [3], [4], így az alkalmazott modellek kielégítik azokat az igényeket, amelyek a nemlineáris regressziós függvények illesztése során szükségszerüek.

Az alkalmazott modellek illesztési pontosságát illetően számottevő eltérést tapasztaltunk. A speciális kettős Awrami-függvények csak a szélsőségektől mentes, egy szélsőértékkel jellemezhető, enyhén aszimmetrikus adatsorok elemzésére voltak alkalmasak ( $\mathrm{R}=98,3 \%-96,7 \%)$. A több szélsőértékkel jellemezhető években gyengébb illesztési pontosság $\left(\mathrm{R}_{2013}=70,6 \% ; \mathrm{R}_{2018}=88,4 \%\right)$ miatt alkalmazási lehetősége a madárvonulás modellezésében korlátozott. A Gauss-függvények speciális lineáris kombinációi a fenti hiányosságot küszöbölik ki. Az adatsorhoz igazított számú újabb Gauss-tagok beépítésével a modell több szélsőérték esetén is alkalmassá tehető a folyamat kellő pontosságú - a biológiai tartalmat tekintve is értelmes - matematikai leképezésére, és a vonulás tetőzésének meghatározására, amit a szélsőséges vonulási karakterisztikájú évek illesztési eredményei jól tükröznek $\left(\mathrm{R}_{2013}=90,4 \%\right.$; $\mathrm{R}_{2018}=97,5 \%$ ).

$\mathrm{Az}$ alkalmazott modellek szélsőértékeinek meghatározásához szükséges differenciálhatóság elégséges feltétele minden esetben teljesül ugyan, de a szélsőértékek koordinátái egyszerü analitikus módszerekkel nem határozhatók meg. Emellett az Awrami és Awrami-modell esetében a szélsőséges karakterisztikájú adathalmazok elemzési lehetősége korlátozott, hiszen a vonulás tetőzését jelző szélsőértékek meghatározásának lehetősége bizonytalan, ami elemi fontosságú a folyamat leírásánál és a további elemzések során (pl.: az időjárási viszonyok vonulásdinamiát befolyásoló szerepének feltárása során) [5].

Az egyes évek vonulásdinamikai sajátságait leíró kettős Awrami függvények esetében a megfelelő paraméterek szorzatai $\left(\mathrm{b}_{6} * \mathrm{~b}_{4} \uparrow ; \mathrm{b}_{2} * \mathrm{~b}_{0} \downarrow\right)$, míg a Gauss-modellek esetén a vonulás jellemző kezdő- és záróidőpontjaihoz (március 1.- április 10.) tartozó mintaszámok. Továbbá az abszolút szélsőértékek alapján számított differenciahányadosok lesznek a regressziós modellek átlagos intenzitásjelző értékei, amelyek segítségével a vonulási csúcsot megelőző és az azt követő függvényszakasz növekedési és csökkenési sajátságai számszerüen kifejezhetők és összevethetők. Mindez lehetővé teszi a folyamat intenzitási viszonyainak matematikai módszerekkel történő leírását.

\section{4. Összefoglaló}

A 2010 és 2019 közötti időszakban Magyarországon a tavaszi mintagyüjtés során terítékre került erdei szalonkák ( $\mathrm{n}=23539$ pld) tavaszi vonulás-dinamikáját speciális, nem lineáris regressziós eljárással vizsgáltuk. A tíz mintavételi időszakban megvalósult monitorig során az országos léptékü, reprezentatív mintavételezés nagy elemszámú adatsorai a vonulásdinamika kellően megalapozott statisztikai elemzését tettek lehetővé. Olyan modelleket adaptáltunk a vizsgált faj tavaszi vonulásának leírására, amelyek alkalmasak a dinamikai eltérések matematikai módszerekkel történő kifejezésére. A ponthalmazok sajátságaihoz igazodó modelleknek több kritériumnak kellett megfelelniük, amit a regressziós eljárás során a vizsgálat tárgyát képező adathalmaz határozott meg. Elvárás volt a korlátosság tulajdonsága, továbbá a vonulási folyamat jellemzése szempontjából kiemelt jelentőséggel bíró egy vagy több szélsőérték meghatározásának lehetősége. A tavaszi szalonkavonulás karakterisztikája az egyes mintavételi időszakok között számottevő eltérést mutatott. Az egyes évek dinamikai lefutásának szemléletes megjelenítéséhez, Awrami-függvények kombinációit, illetve kétszeres, és háromszoros Gauss-függvények lineáris kombinációit alkalmaztuk. 
A Gauss-függvényekből előállított modellek bizonyultak a legkedvezőbbnek mind a normál, mind pedig a szélsőséges karakterisztikával jellemezhető évek esetén, amit az illeszkedési pontosság magas - 90,3\% és 98,7\% közötti - értékei jeleznek. Az alkalmazott Gauss-modellek számított szélsőértékei a vonulási csúcsok meghatározását minden esetben lehetővé tették. A vonulási folyamat változási intenzitásának értékeléséhez a modell alapján számított differenciahányadosok szolgáltattak információt (1. táblázat).

\section{A fentiek alapján a vizsgálati évek a következőképpen jellemezhetők:}

- Normál, aszimmetrikus Gauss-görbe jellegü, egy maximummal jellemezhető karakterisztikájú évek: 2010, 2011, 2012; 2015, 2017.

- Előretolódott, aszimmetrikus, ellaposodó Gauss görbe jellegü, több szélsőértékkel jellemezhető karakterisztikájú évek: 2014, 2016, 2019.

- Zavart karakterisztikájú, több szélsőértékkel jellemezhető évek: 2013, 2018.

Eredményeink alapján az Gauss-függvények lineáris kombinációi alkalmasnak bizonyultak a tavaszi madárvonulás dinamikai sajátságainak modellezésére, a karakterisztika sajátságainak értékelésére, így alkalmazásukat javasoljuk a hasonló dinamikájú biológiai folyamatok statisztikai értékelése során.

\section{Köszönetnyilvánítás.}

A vonulásdinamika értékelését megalapozó adatgyüjtés az Országos Magyar Vadászati Védegylet koordinálásával müködő Erdei Szalonka Monitoring Program keretében valósult meg. Köszönjük a mintagyüjtő vadásztársak áldozatos munkáját, valamint a monitoring működtetésében közreműködők segítségét.

\section{Irodalomjegyzék}

[1] Faragó S., László R., Bende A., Az erdei szalonka (Scolopax rusticola) teríték monitoring eredményei 2010ben Magyarországon. Results of the Hungarian Woodcock (Scolopax rusticola) Bag monitoring in 2010. Magyar Vízivad Közlemények 22. (2012a), 285-296.

[2] Faragó S., László R., Bende A., Az erdei szalonka (Scolopax rusticola) teríték monitoring eredményei 2011ben Magyarországon. Results of the Hungarian Woodcock (Scolopax rusticola) Bag monitoring in 2011. Magyar Vízivad Közlemények 22. (2012b), 297-310.

[3] Faragó S., László R., Bende A. (2014): Az erdei szalonka (Scolopax rusticola) teríték monitoring eredményei 2012-ben Magyarországon - Results of the Hungarian Woodcock (Scolopax rusticola) Bag Monitoring in 2012. Magyar Vizivad Közlemények 24 283-295.

[4] Faragó S., László, R., Bende A., Az erdei szalonka (Scolopax rusticola) teríték monitoring eredményei 2013-ban Magyarországon - Results of the Hungarian Woodcock (Scolopax rusticola) Bag Monitoring in 2013. Magyar Vízivad Közlemények 25. (2015a), 289-302.

[5] Faragó S., László R., Bende A., Az erdei szalonka (Scolopax rusticola) ivararányának alakulása 2010-2014 között Magyarországon. In: Bidló, A. \& Facskó, F. (szerk.) V. Kari Tudományos Konferencia. Sopron, 2015.10.25. Konferencia Kiadvány, Nyugat-magyarországi Egyetem, Soproni Egyetem Kiadó. (2015b), 105-107.

[6] Faragó S., László R., Bende A., Az erdei szalonka (Scolopax rusticola) teríték monitoring eredményei 2014 ben Magyarországon - Results of the Hungarian Woodcock (Scolopax rusticola) bag monitoring in 2014. Magyar Vízivad Közlemények 27. (2016), 284-296.

[7] Schally G., Az erdei szalonka (Scolopax rusticola) megfigyelési és elejtési adatainak vizsgálata Magyarországon 2009-2018 között. PhD doktori értekezés, Szent István Egyetem, Gödöllő. (2020). p. 114. 
[8] Csanády V., Gazdasági változások regressziós vizsgálata, Dimenziók IV. (2017), 39-49. doi:10.20312/dim.2017.06

[9] Csanády V., Kettős Awrami függvény alkalmazása, Dimenziók VI. (2018), 41-48. doi:10.20312/dim.2018.05

[10] Csanády V., Kettős Gauss függvény alkalmazása, Dimenziók VII. (2019), 37-47. doi:10.20312/dim.2019.05

[11] Csanády V., Nemlineáris regressziók alkalmazása gyakorlati példákban, Dimenziók I. (2013), 19-26. 